\title{
The UK's total nitrogen budget from 1990 to 2020: a transition from source to sink?
}

\author{
F. Worrall · T. P. Burt • N. J. K. Howden · M. J. Whelan
}

Received: 25 February 2016/Accepted: 26 July 2016/Published online: 19 August 2016

(C) The Author(s) 2016. This article is published with open access at Springerlink.com

\begin{abstract}
This study estimates the annual total nitrogen balance of the UK from 1990 to 2020. The following inputs of nitrogen are considered: inorganic fertilizer, atmospheric deposition; food and feed imports; and biological nitrogen fixation. The outputs considered compose: atmospheric emissions; direct losses of sewage and industrial effluent to the sea; fluvial losses at source; food and feed exports; and terrestrial denitrification. It is shown that: (1) Inputs of inorganic fertilizer declined significantly over the study period with both atmospheric deposition and
\end{abstract}

Responsible Editor: John Harrison

Electronic supplementary material The online version of this article (doi:10.1007/s10533-016-0234-4) contains supplementary material, which is available to authorized users.

F. Worrall $(\bowtie)$

Dept. of Earth Sciences, Science Laboratories, University of Durham, South Road, Durham DH1 3LE, UK

e-mail: fred.worrall@durham.ac.uk

T. P. Burt

Dept. of Geography, Science Laboratories, University of Durham, South Road, Durham DH1 3LE, UK

\section{N. J. K. Howden}

Department of Civil Engineering, University of Bristol, Queen's Building, University Walk, Bristol BS8 1TR, UK

\section{J. Whelan}

Department of Geography, University of Leicester, Leicester LE1 7RH, UK food and feed imports significantly increasing. (2) Outputs of total $\mathrm{N}$ also significantly declined with all output pathways decreasing except for atmospheric emissions and terrestrial denitrification to $\mathrm{N}_{2}$. (3) The UK was a net source of total nitrogen in 1990 of approximately $\quad-1941 \pm 224$ kilotonnes N/year ( -8 tonnes $\mathrm{N} / \mathrm{km}^{2} /$ year; inter-quartile range of \pm 0.9 tonnes $/ \mathrm{km}^{2} /$ year). However, by 2012 , this net nitrogen source had decreased to about $-1446 \pm 195$ kilotonnes $\mathrm{N} /$ year $\left(-5.9\right.$ tonnes $\mathrm{N} / \mathrm{km}^{2} /$ year). The future total $\mathrm{N}$ balance of the UK is being driven by declines in outputs rather than changes in inputs. The largest declines are in the atmospheric emissions of reactive nitrogen $\left(\mathrm{N}_{\mathrm{r}}\right)$ and the fluvial flux of $\mathrm{N}$ such that by 2020 to the total $\mathrm{N}$ budget is predicted to be $-1042( \pm 246)$ kilotonnes $\mathrm{N} /$ year ( -4.2 tonnes $\mathrm{N} / \mathrm{km}^{2} /$ year) and by 2031 the UK would be a net sink of total $\mathrm{N}$.

Keywords Nitrate Reactive nitrogen · Atmospheric nitrogen · Fluvial nitrogen · Biological nitrogen fixation - National budget

\section{Introduction}

The Organisation for Economic Cooperation and Development (OECD) has identified N balance as a priority agri-environmental indicator (OECD 2003). As a result, several national or supra-national $\mathrm{N}$ balance studies have been conducted covering, not only the terrestrial biosphere or agricultural balance, but also entire regions. For example, $\mathrm{N}$ balance studies 
include the agricultural balance of the UK (Lord et al. 2002); entire countries, e.g. Finland (Salo et al. 2007); and Canada (Janzen et al. 2003); and even the entire European Union with individual national summaries (de Vries et al. 2011a; Leip et al. 2011). Nevertheless, it has proven difficult to provide a complete $\mathrm{N}$ budget at such large scales, for three main reasons. Firstly, it is always difficult to include all possible uptake and release pathways. For example, Lord et al. (2002) when considering the agricultural balance of the UK, argued that estimates of denitrification were too uncertain to include in their analysis of the $\mathrm{N}$ balance of all UK agricultural land. Indeed, Parris (1998) argued that N balances such as that proposed by Lord et al. (2002) could not be used as predictors of nutrient pollution because of their incomplete nature. Part of this issue is one of the differing boundaries drawn by studies, with some studies considering only the terrestrial ecosystem but not the aquatic ecosystem (e.g. Hemond 1983); a political boundary (e.g. Ti et al. 2011); or certain sectors of the economy (e.g. Dalgaard et al. 2011). Within some of these entities consideration of some fluxes would be inappropriate, e.g. for a consideration of the agricultural sector, it would not be appropriate to consider industrial sources of $\mathrm{N}_{2} \mathrm{O}$.

Secondly, published studies have generally only considered fluxes of reactive nitrogen $\left(\mathrm{N}_{\mathrm{r}}\right.$-Galloway et al. 2004) and not the total $\mathrm{N}$ flux. Reactive $\mathrm{N}$ would not include consideration of denitrification to $\mathrm{N}_{2}$ or industrial emissions of $\mathrm{N}_{2}$. By not considering total $\mathrm{N}$ studies, it is not possible to know whether there is net accumulation or loss from a region, and as a result, there is an assumption which infers no long-term net accumulation or depletion in the terrestrial biosphere or at the country level (Galloway et al. 2004; Ayres et al. 1994). Although definitions of the boundary of the system being considered vary, a number studies across a range of scales and systems have had to assume a steady state of total $\mathrm{N}$ from considering only reactive Parris (1998) showed that the terrestrial biosphere in the majority of OECD countries was a net sink of $\mathrm{N}_{\mathrm{r}}$, but the apparent sink size was dismissed as insignificant and easily balanced by likely fluxes of $\mathrm{N}_{2}$ from terrestrial or aquatic denitrification that were not quantified. Kroeze et al. (2003), in presenting an N budget for the entire Netherlands, estimated an $\mathrm{N}_{\mathrm{r}}$ sink of 469 kilotonnes N/year in 1995, which they assumed was balanced by aquatic and terrestrial denitrification to $\mathrm{N}_{2}$. However, Kroeze et al. (2003) did not attempt to estimate the probable magnitude of either terrestrial or aquatic denitrification to $\mathrm{N}_{2}$. Even the most recent studies have been limited to $\mathrm{N}_{\mathrm{r}}$ (e.g. Parfitt et al. 2008; Sutton et al. 2011a; Ti et al. 2011) are limited to subnational regions (e.g. Howarth et al. 2006), or are limited to the terrestrial biosphere rather than a geographical unit (e.g. Oláh and Oláh 1996). Billen et al. (2012) when considering the $\mathrm{N}$ imprint of Paris, did consider $\mathrm{N}_{2}$ uptake but not gaseous releases of $\mathrm{N}$ to the atmosphere of any species of N. Schlesinger and Bernhardt (2013) have outlined the global total N cycle. Worrall et al. (2015) provided a total $\mathrm{N}$ budget for a region (the Thames basin, approx. $10,000 \mathrm{~km}^{2}$ ) but not for a whole country. Galloway et al. (2004) maintained that the assumption of no long term accumulation could be justified by the fact that concentrations of $\mathrm{N}_{2} \mathrm{O}$ in the global atmosphere, as measured in ice core bubbles, had been steady since $1000 \mathrm{AD}$. However, $\mathrm{N}_{2} \mathrm{O}$ concentrations have actually risen by $20 \%$ in the last 200 years (Wolff and Spahni 2007). Furthermore, $\delta^{15} \mathrm{~N}$ values of atmospheric $\mathrm{N}_{2} \mathrm{O}$ have declined, which has been ascribed to increased terrestrial and aquatic denitrification caused by an increased use of inorganic fertilizers (Sowers et al. 2002). Denitrification tends to select preferentially for ${ }^{14} \mathrm{~N}$ over ${ }^{15} \mathrm{~N}$ resulting in $\delta^{15} \mathrm{~N}$ enriched nitrate remaining and $\delta^{15} \mathrm{~N}$-depleted $\mathrm{N}_{2}$ and $\mathrm{N}_{2} \mathrm{O}$ emitted to the atmosphere (e.g. Mariotti 1986). The residence time of $\mathrm{N}_{2} \mathrm{O}$ in the atmosphere is of the order of 100 years (Brimblecombe 1996), which means that recent changes may not be evident for several years or even decades. In respect of the ice core record, no data for the last 25 years have yet been published (Spahni et al. 2005) and before that the temporal resolution was only between 10 and 20 years (Etheridge et al. 1998). Moreover, because the assumption of no long term accumulation is based upon a global perspective, it does not preclude individual regions or countries being net sources or sinks.

Thirdly, most studies have been unable to consider multiple years, but it is known that the timescale for adjustments in net soil mineralization or immobilization (resulting from land use changes, for example), can be many decades (Addiscott 1998; Whitmore et al. 1992). Budgets for a single year may, therefore, be misleading when viewed outside a context of continuing environmental change.

Worrall et al. (2009a) calculated a detailed fluvial flux balance of $\mathrm{N}_{\mathrm{r}}$ for the UK from 1974 to 2005 and showed that, not only is the UK a "hotspot" for fluvial 
$\mathrm{N}_{\mathrm{r}}$ flux, with higher exports of dissolved nitrogen than those documented for any other region of comparable size in the world, but that the dissolved $\mathrm{N}_{\mathrm{r}}$ flux appears to be increasing significantly. Furthermore, increasing fluvial fluxes were occurring at time when $\mathrm{N}_{\mathrm{r}}$ inputs were decreasing and so, although the UK remained a net sink of $\mathrm{N}_{\mathrm{r}}$ the size of that sink was declining. However, Worrall et al. (2009) could not estimate the magnitude of either aquatic or terrestrial denitrification. Furthermore, although they did consider atmospheric emissions of reactive $\mathrm{N}_{\mathrm{r}}$ species from industry (particularly $\mathrm{N}_{2} \mathrm{O}$ and $\mathrm{NH}_{3}$ but not of organic $\mathrm{N}$ species), they did not consider the atmospheric emissions of $\mathrm{N}_{2}$ from industrial sources and so could not estimate a total $\mathrm{N}$ budget of the UK. Likewise, Worrall et al. (2015) were able estimate a total $\mathrm{N}$ budget for a large region but only considered the terrestrial and aquatic ecosystems and so did not have to consider industrial emissions.

The aim of this study, therefore, was to fill the current gaps, that is, no national estimate of total $\mathrm{N}$ budget including reactive and non-reactive $\mathrm{N}$ species, industrial sources and sinks, and $\mathrm{N}$ embedded in food and feed trade over a series of years. In this way it will be possible to assess where $\mathrm{N}$ is going in the environment.

\section{Approach and methodology}

This study includes all major $\mathrm{N}$ input and output pathways (Fig. 1) over a period of time set by the length of the shortest record. It was possible to calculate all the fluxes for a total $\mathrm{N}$ budget between 1990 and 2012. However, more recent estimates were possible for some individual components (pathways)and where that was the case, values for that component are reported up to the most recent date. For all uptake and release pathways that could be included, the time series from 1990 to at least 2012 (or whichever is the latest year for which data were available) was projected forward to 2020 . If there was a significant trend in a budget component, then it was projected forward to 2020. Significance was assessed at the $95 \%$ probability of being different from zero unless stated otherwise Where no significant trend was identified, the value estimated for 2020 was randomly selected from the period 1990 to the latest year available. In some cases, a linear extrapolation may be
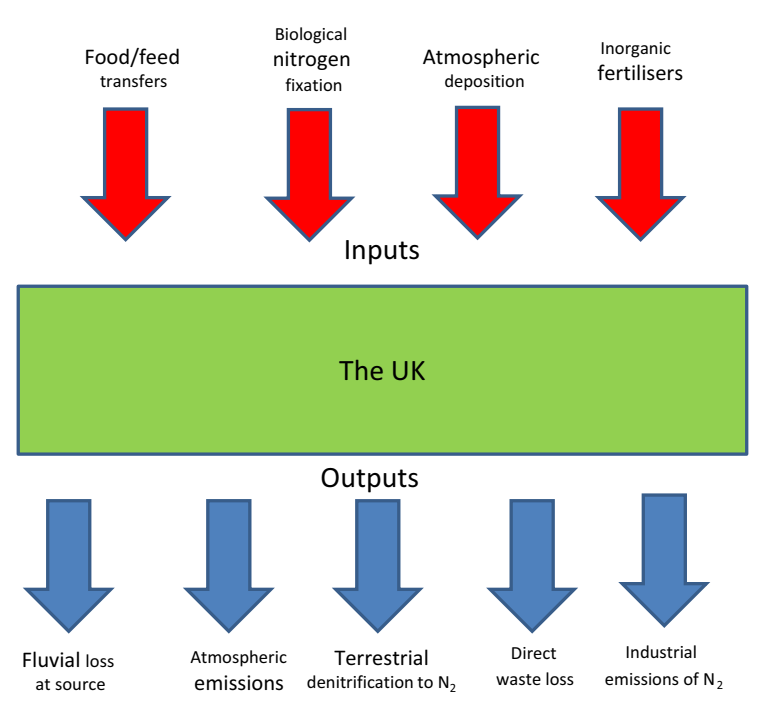

Fig. 1 Schematic representation of the total $\mathrm{N}$ budget for the UK

overly simplistic as the cause for the recent trends is known and could be extrapolated into the future, in which case such a prediction was made alongside the simple linear extrapolation. By performing these projections, the total $\mathrm{N}$ budget could be forecast for the year 2020 .

Where values were available only for Great Britain and not for the UK as a whole, i.e. the area of Northern Ireland was not included, the available annual data were rescaled proportionally based upon area of the UK so as to include Northern Ireland.

The quality of the individual records used to calculate different $\mathrm{N}$ fluxes varies considerably. We therefore attempted to assess the uncertainty associated with each input and output. Most of the nitrogen fluxes needed for a complete $\mathrm{N}$ budget are only reported within government or other published data sources. The published values are used, rather than being recalculated within this study, since the original data were not available. Consequently, the error estimation provided by each individual source was accepted. In some cases, no error or uncertainty estimate was given or the error estimate provided was not credible and in these cases a percentage error from the median estimate of $\pm 80 \%$ was assumed. This error estimate was not the largest uncertainty found for any input or output but it was taken as generous. In other cases, although the reported flux error is given as a range, it is not always clear what this error actually represents (e.g. range, inter-quartile range, confidence 
intervals). Given the uncertainty associated with each input and output, the total $\mathrm{N}$ budget for any year was calculated as the sum of individual inputs and outputs, where a value was taken at random from within the range that could be defined for each input or output; this was repeated 500 times with the best estimate of the total $\mathrm{N}$ budget being the median of that distribution. In this way, estimates of the annual total $\mathrm{N}$ budget were calculated along with uncertainty limits. This approach to budget summation and uncertainty analysis is the same as used in Worrall et al. (2009a, 2015).

The convention used by this study is that a negative budget is a source of $\mathrm{N}$ from the $\mathrm{UK}$ to adjacent systems (this may be to oceans, atmosphere or exported as food and feed). Conversely, positive values of the total $\mathrm{N}$ budget were defined as sinks to or occurring in the UK.

\section{$\mathrm{N}$ inputs}

The following inputs were considered: atmospheric deposition of $\mathrm{N}$ (wet and dry); biological fixation of atmospheric $\mathrm{N}$; net trans-boundary transfer of $\mathrm{N}$ in food and feed into and out of the UK; and synthetic inorganic fertilizer applications. The vast majority of animal wastes in the UK are returned to the land on the same farm as they are produced or on nearby farm units and so represent an internal transfer with no net loss or gain from the UK. Any effect of animal waste inputs upon leaching or atmospheric emissions would be accounted for in the examination of those particular pathways. Equally, by taking the boundary of the study system as the UK, there are only a limited number of trans-boundary river catchments (There is only one cross-border river in the UK (River Blackwater between Northern Ireland and the Republic of Ireland) which is only $1507 \mathrm{~km}^{2}$ in size and most of which is in the UK and not the Republic of Ireland). This means that neither fluvial flux across these boundaries nor use of irrigation water have to be considered as an input or output. The UK Government banned the burning of crop residues in 1993 and most residues are now left in field after harvest. However, the extent to which this will impact the terrestrial nitrogen budget is currently not known and values of what this represents in terms of $\mathrm{N}$ transfer to the soil are not available. Smil (1999) recognized that records of crop residues are not maintained by any country and so this cannot be estimated here either.
Consistent atmospheric deposition records for the UK have been maintained since 1986 (Fowler et al. 2005) although, the fluxes reported are not complete with respect to wet and dry deposition of either reduced or oxidized forms of nitrogen. We therefore extended the record of dry deposition by linear interpolation of the ratio of wet to dry deposition in those years where both were reported. Fowler et al. (2005) only give records to 2001 but further records are available from the Centre for Ecology and Hydrology (CEH: www.ceh.ac.uk) for 2004-2012. In order to get flux estimates for 2002 and 2003, linear interpolation was used. Neither Fowler et al. (2005) nor CEH quote an error for their deposition values, but CEH quote deposition to 2 d.p. implying the error to be of the order of $\pm 1 \%$-this study did not consider this a credible error, therefore we have ascribed an error of $\pm 80 \%$ for reasons outlined above. The atmospheric deposition estimates of, Fowler et al. (2005), Simpson et al. (2011) and CEH (www.ceh.ac.uk) do not include an estimate of DON in wet or dry deposition. Cape et al. (2012) consider DON in precipitation across Europe but do not report for sites within the UK. However, two studies have considered the DON deposition at UK sites. Annual figures of DON deposition at Moor House have been calculated for the period 1992 to 2003 by Worrall et al. (2006) and this can be extended through to 2012 using data collected by the UK Environmental Change Network (www. ecn.ac.uk). Benitez et al. (2012) measured nitrogen speciation at a site in south west Scotland and reported the percentage as organic nitrogen. The record for atmospheric $\mathrm{N}$ deposition includes deposition from any source both inside and outside the UK.

Biological nitrogen fixation (BNF) can occur in all ecosystems and can represent a significant input of nitrogen. For agricultural systems the approach of Smil (1999) was used. Although updates to this method have been published by, Herridge et al. (2008) these updates are for crop and land use types not found in the UK. The area of nitrogen-fixing crops for the UK was considered to consist exclusively of legumes (predominantly beans and peas) and clover, as part of crop rotation. The area of each of these crop types was available from 1986 onwards as part of the UK agricultural annual census returns (MAFF 1975/ 2000; DEFRA 2001). For both clover and legumes, the middle estimate of $\mathrm{N}$ fixation as reported by Smil (1999) was used. For biological fixation in natural 
ecosystems, as opposed to agricultural systems, the approach of Cleveland et al. (1999) was used. For the UK it was assumed that the majority of natural ecosystems fell into the classes of temperate forest or temperate grassland as defined by Cleveland et al. (1999). The area of UK forest, which this study considers as all forestry types both commercial and semi-natural, was available from statistics held by the Forestry Commission (2011) for the years 1965, 1980, 1990, 1998-2002, 2007, 2011, and 2014: linear interpolation was used to estimate annual values. The area of the UK that is not under forestry, clover or peas and beans, is taken as equivalent to temperate grassland as defined by Cleveland et al. (1999). The error in BNF can be calculated by using the ranges for fixation published by Smil (1999) and Cleveland et al. (1999). Estimation of BNF was possible up to 2012.

Nitrogen is redistributed across national boundaries with food and feed transfers as well as plant and seed transfers. Boyer et al. (2002) estimated the food and feed transfer flux of nitrogen for the eastern USA by considering human and animal demand relative to production within the region. In our study an alternative approach has been adopted. We used commodity trade data to estimate the nitrogen exports or imports for the UK. The tonnage of imports versus exports was compared for wheat, barley, oats, maize, linseed, oilseed, sugar, potatoes, vegetables, flowers, fruit, cattle, sheep, pigs, chickens, fish, butter, cheese, cream and milk (powdered and condensed). The balance of trade in food and feedstuff commodities was available from 1991 to 2012 (MAFF 1975/2000; DEFRA 2001). The balance of trade in each chosen commodity was converted to a balance of nitrogen trade using typical nitrogen contents of common foodstuffs (Rossi et al. 2004) including fish (McCance and Widdowson 2002) - N content conversion values for the food and feed types considered are given in the Supplementary Material (Table S1). The import or export of plant and seeds is not recorded in UK agriculture commodity records although some will be included in the trade values for grains. However, plant and seed transfer represent only a small fraction of the total trade in food and feedstuffs and so their exclusion is likely to make little difference. For compositional data, freshwater fish were considered as salmon and landings of sea fish and shellfish were considered as haddock and crab respectively as these were the most common species of each. The nitrogen contents of food reported by Rossi et al. (2004) and McCance and Widdowson (2002) have maximum and minimum values and represent an uncertainty of $\pm 6 \%$, however, the commodity trade volumes are reported without error estimates and so the error estimate from transnational food and feed transfers were taken as the default of $\pm 80 \%$. This range was used to calculate the error in the flux of $\mathrm{N}$ as food and feed transfers. Data for food and feed transfers were available through to 2012. The study of Sutton et al. (2011) did not consider trans-boundary food and feed transfers between European Union countries or with areas outside the European Union.

Figures for the use of synthetic inorganic fertilizer in the UK were derived for the period 1974 to 2012 from surveys published by the Fertilizer Manufacturers Association and the Environment Agency of England and Wales (British Survey of Fertilizer Practice, 2013). The values of annual fertilizer input are reported with an estimated standard error of $\pm 9 \%$.

\section{$\mathrm{N}$ outputs}

This study considers the following output and release pathways (Fig. 1): atmospheric emissions of $\mathrm{NH}_{3}$ volatilisation, $\mathrm{NO}$ and $\mathrm{N}_{2} \mathrm{O}$; industrial emissions of $\mathrm{N}_{2}$; terrestrial denitrification of $\mathrm{N}_{2}$; the fluvial flux at source (including: nitrate, nitrite, ammonium, dissolved organic nitrogen [DON], and particulate organic nitrogen [PON]); and direct outputs of human sewage and waste effluent to surface waters beyond the UK tidal limit. These divisions between output and release pathways were used because they correspond to the available data sources.

Estimates of acidifying compound emissions (NOx, SOx, $\mathrm{HCl}$ and $\mathrm{HF}$ ) are available back to 1970 (e.g. Dore et al. 2007), including those from agriculture (such as $\mathrm{N}_{2} \mathrm{O}$ and $\mathrm{NO}$ emissions from the land surface, but not terrestrial or aquatic denitrification to $\mathrm{N}_{2}$ nor emissions of $\mathrm{N}_{2}$ from industrial sources). Here, the records of $\mathrm{N}_{\mathrm{r}}$ emissions were extended to 2012 by reference to the UK's National Atmsopheric Emissions Inventory (http://naei.defra.gov.uk/) No error statement was given with these sources and so again we have arbitrarily assumed an error of $\pm 80 \%$.

Industrial emissions of $\mathrm{N}_{2}$ are not reported in any UK government report. However, carbon emissions from hydrocarbon fuels are reported for the UK (Thomas et al. 2011; DECC 2012-2015). The majority 
of hydrocarbon fuels commonly used contain a proportion of nitrogen and so, as carbon-based fuels are consumed, they also release nitrogen. The UK government, as part of its greenhouse gas emission reporting commitments, reports the annual flux of $\mathrm{CO}_{2}$ equivalents split between $\mathrm{CO}_{2}$, methane and nonmethane volatile organic carbons (NMVOC), along with the amount of each coming from solid, petrol or gas sources. If the $\mathrm{C}: \mathrm{N}$ ratio of different fuels is known, then it is possible to estimate the annual $\mathrm{N}$ release from industrial emissions. The industrial emissions of $\mathrm{N}_{2} \mathrm{O}$, $\mathrm{NO}$ and $\mathrm{NH}_{3}$ are known from the National Atmospheric Emissions Inventory. The difference between the estimated total $\mathrm{N}$ lost from burning of fuels and that recorded as industrial emissions represents an "unaccounted for" loss which we assume to be predominantly $\mathrm{N}_{2}$, although some could also be volatile organic nitrogen (VON). However, since all calculations were performed on the basis of the mass of $\mathrm{N}$, then the exact form of this unaccounted emission is not important. The error in this emission, henceforward assumed to be the industrial emission of $\mathrm{N}_{2}$, is a combination of the errors in the recorded emissions of $\mathrm{CO}_{2}$, methane and NMVOC and the variation in the $\mathrm{C}: \mathrm{N}$ ratio of different fuels. For solid fuels values for bituminous coal were used $\mathrm{C}: \mathrm{N}=0.011$ to 0.020 (Burchill 1989); for petrols, $\mathrm{C}: \mathrm{N}=0.001$ to 0.024 (Rickard and Fulker 1996); and natural gas, $\mathrm{C}: \mathrm{N}=0.000$ to 0.071 (Neuwirth 2008). For the latter, the $\mathrm{C}: \mathrm{N}$ ratio was taken as that of the natural gas as supplied rather than its original composition; $\mathrm{N}_{2}$ content of natural gas in geological reservoirs can approach $100 \%$ by volume (Krooss et al. 1995). High-temperature burning of fuels can result in the conversion of atmospheric $\mathrm{N}_{2}$ to NOx which, although it results in no direct additional nitrogen release or uptake from the atmosphere there is an effect on atmospheric nitrogen speciation with concomitant consequences for atmospheric, residence time of N. However, the process occurs only at the high temperatures (typically greater than $1600{ }^{\circ} \mathrm{C}$ ) and, although the switch in residence time is large $\left(10^{6}\right.$ years for $\mathrm{N}_{2}$ to $10^{2}$ years for $\mathrm{NOx}-$ ) Brimblecombe (1996), the residence time of NOx is still longer than the time course of this study meaning that any increase, or decrease, in high temperature combustion over the course of the study would not have worked its way through to the record. Equally, this study was primarily concerned with the total $\mathrm{N}$ budget and not the individual species and the high-temperature conversion of atmospheric $\mathrm{N}_{2}$ to NOx does not alter the mass of atmospheric $\mathrm{N}$ in the term of this study. Values of the industrial emissions of $\mathrm{N}_{2}$ are reported to 2012.

Terrestrial denitrification to $\mathrm{N}_{2}$ was estimated using the review of Barton et al. (1999). They examined 95 studies of $\mathrm{N}_{2}$ flux from natural systems and were able to establish significant differences in the annual $\mathrm{N}_{2}$ flux between land uses. Given the land use history for the UK reconstructed for the calculation of the BNF, the average values and ranges found for distinct land uses can be used to calculate the flux history of terrestrial denitrification to $\mathrm{N}_{2}$ based upon the studies reported by Barton et al. (1999) reported for the UK. The distinct land uses that could be considered are forestry, rough grazing land, fertilized grassland and cropland. The uncertainty in this flux pathway comes from the variation in the estimates of denitrification for each land use type as catalogued by Barton et al. (1999) and was $\pm 96 \%$.

The fluvial flux of $\mathrm{N}$ from the terrestrial source to the fluvial network is not measured nationally, however, measurements of the flux of $\mathrm{N}$ species at the tidal limit are made. If the flux of $\mathrm{N}$ species at the tidal limit is known then flux at the source can be estimated if both in-stream losses and changes in groundwater storage of $\mathrm{N}$ species can be calculated. The data used for calculation of the fluvial flux at the tidal limit were obtained from the Harmonised Monitoring Scheme (HMS). The HMS was established in 1974 to measure important hydrochemical fluxes to the North Atlantic and to allow any trends to be identified (Simpson 1980). Here, we considered only those HMS sites at the tidal limits of rivers. A range of water quality parameters are measured at these sites and those pertinent to this study are nitrogen as nitrate, ammonium and nitrite as well as the river discharge at the time of sampling.

The HMS does not measure DON. Here, it was assumed that DON can be derived from the flux of DOC. Particulate organic nitrogen (PON) is also not measured in the HMS. However, Worrall et al. (2014) calculated particulate organic matter (POM) flux at UK tidal limit based upon HMS monitoring of suspended sediment concentration and sediment ash content. The flux of DOC and POM is not the flux of DON or PON. Worrall et al. (2016) used POM data collected as part of the LOIS project (Neal 2003) to 
give PON contents of POM. The LOIS project analysed 2484 samples for POM across 5 years for 16 sites across 13 rivers (Rivers Aire, Calder, Derwent, Don, Great Ouse, Nidd, Yorkshire Ouse, Swale, Trent, Tweed, Ure, Wear and Wharfe-Robson and Neal 1997) for the Humber Basin $\left(26,109 \mathrm{~km}^{2} ; 17 \%\right.$ of the UK catchment area). Across 5 years (1994-1998) and 16 sites across 13 rivers. The median $\mathrm{POC} / \mathrm{PON} \mathrm{C} / \mathrm{N}$ ratio was 11.5 with an interquartile range of 9.2 to 14.3 .

Given the determinand and flow data, the annual flux was calculated using the method proposed by Worrall et al. (2014) based on only using those siteyear combinations where there were a minimum of 12 samples collected for that site in that year. The method of Worrall et al. (2014) has been shown to be more accurate and precise for the sparsely sampled data typical of national-scale monitoring than other methods, e.g. Littlewood and Marsh (1980). The annual flux estimates for nitrate, nitrite, ammonia, DON and PON for individual sites were upscaled to a value for the national UK flux using the area-weighted approach of Worrall et al. (2007) as this method is not sensitive to missing data for any site in any year and allows for the better reflection of regional differences across the UK.

For the fluvial flux, the error was estimated using the approach taken for DOC by Worrall et al. (2007) i.e. errors due to both sampling frequency and upscaling to the national boundaries were estimated - the error due to the flux calculation method was shown to be small (precision $= \pm 2 \%$, accuracy $=-8 \%$ for monthly sampled data) compared to that due to upscaling to the national scale (precision $= \pm 15 \%)$. For the calculation of DON and PON fluxes requires use of literature estimates of the $\mathrm{C} / \mathrm{N}$ ratio of the dissolved and suspended matter and the organic carbon content of the suspended sediment.

Aquatic denitrification to $\mathrm{N}_{2}$ was included in the estimated in-stream losses. The fluvial flux calculated from the HMS data represents the loss at the tidal limit of the UK and not the land to surface water flux (i.e. as the water enters the fluvial network). This will be an underestimate of losses from the terrestrial biosphere as it does not account for in-stream losses, such as immobilisation in the stream biomass (although this would be a temporary store) or transfers to the atmosphere via denitrification by regional $\mathrm{N}$ budgets. The processing of nitrogen species in streams was not considered by Smil (1999) or Boyer et al. $(2002,2005)$ but was by Marsh 1980. Rivers can also be sources of nitrogen via PON and DON release from sediment stores or from the decomposition of plant material. Here, the losses of $\mathrm{N}$ within the UK fluvial system were estimated by the methods developed by Worrall et al. (2012, 2014). Calculated N fluxes (DON, nitrate, ammonium and PON) were compared across 169 catchments and once differences in land use and soil type were accounted for, then the change in $\mathrm{N}_{\mathrm{r}}$ fluxes with catchment size becomes a measure of the net watershed loss. The error in the estimate of the instream losses in transit was calculated from the fit of the regression equations-this was $\pm 11 \%$.

Flux to groundwater could be considered as just $\mathrm{N}$ storage rather than as a sink or source but given the long residence times in many aquifers and increasing concentrations of nitrate in some UK groundwater bodies (Stuart et al. 2007), we consider it as a sink of $\mathrm{N}_{\mathrm{r}}$ for the purposes of this study. Significant groundwater bodies cover between 10 and $50 \%$ of the UK land area and contain a water volume equivalent of between 1 and $10 \mathrm{~m}$ where there is an aquifer. This means that an increase in average groundwater $\mathrm{N}$ concentration of just $1 \mathrm{mg} \mathrm{N} / \mathrm{l}$ (as reported in the UK since 1990 by Stuart et al. (2007)) could represent an additional 300 kilotonnes $\mathrm{N}$ of storage. If the fluvial flux of nitrogen is considered at both the tidal limit and at its source, then it might be considered that flux via groundwater is accounted for, however, this is not true for three reasons. Firstly, the concentration of nitrogen in UK groundwater is increasing (Stuart et al. 2007) and the source of this additional $\mathrm{N}$ must be accounted for. Secondly, there is a long lag effect due to passage through the groundwater, e.g. 39 years for the River Thames (Howden et al. 2011). Thirdly, as a proportion of flow through the soil directly recharges to groundwater and does not enter the stream network then this represents a flux of nitrogen not accounted for by assessment of at source losses from soil to the stream network. Therefore, the values reported by Stuart et al. (2007) were assumed to cover the sink to groundwater between 1990 and 2012, and thereafter the groundwater sink was assumed to decrease to zero in 2020 even though it would still represent a large store nitrogen we have assumed that it would no longer be accumulating $\mathrm{N}$. The uncertainty in the trend, and therefore the groundwater accumulation, was taken from Stuart et al. (2007) as $\pm 50 \%$. 
The direct flux of sewage and industrial wastes to the sea from the UK are reported as part of UK commitments to a series of international agreements and treaties (Bellamy and Wilkinson 2001; OSPAR Commission 2010). The OSPAR Commission (2010) reports the upper and lower limit of direct flux of nitrate from the UK but the errors quoted do not seem credible: the maximum quoted error for any sea area in 2008 was $\pm 4.5 \%$. Thus for the sake of this study the error was assumed to be equivalent to that of the fluvial flux, i.e. $\pm 15 \%$.

The sources of information for each pathway; the uncertainty assumed and the interpolation method used for projection are summarised in Table S2.

\section{Results}

$\mathrm{N}$ inputs

Data for all the estimated ranges of each input pathway are summarized in Table 1. The proportion of total input represented by each pathway in 1990 compared to 2012 is shown in Fig. 2, with the breakdown of the budget being given in Table 1 for 1990, 2012 and projected to 2020 (all preferred values for $\mathrm{N}$ inputs are given in Table S3).

For atmospheric deposition of total $\mathrm{N}$, a DON deposition of between 0.01 and 0.15 tonnes $\mathrm{N} / \mathrm{km}^{2}$ / year ( 0.1 to $1.5 \mathrm{~kg} \mathrm{~N} / \mathrm{ha} /$ year) was reported by Worrall et al. (2006) at Moor House with no significant trend between 1993 and 2005. Considering data from Moor House up to 2012 did not change the range of values of DON atmospheric input or indicate a significant trend upon that input. If this DON deposition is scaled across the UK, then the total $\mathrm{N}$ import would be between 2 and 37 kilotonnes N/year. Including the DON deposition estimates into those reported by Fowler et al. (2005) and from the CEH reports, the total $\mathrm{N}$ deposition varied from 298 kilotonnes N/year in 1990 to 366 kilotonnes N/year in 2012 with a peak value in 2001 of 393 kilotonnes N/year. As discussed above, no reasonable error estimate can be provided and only a slight, but significant upward trend in this input could be found (gradient $=3.5$ kilotonnes $\mathrm{N} /$ year $^{2}, \mathrm{r}^{2}=0.56, \mathrm{n}=23$ ) giving an estimate of $\mathrm{N}$ deposition in 2020 of 421 kilotonnes N/year. Alternatively, a visual examination of the time series of total $\mathrm{N}$ deposition suggest no change since 2001 which would give a value in 2020 of 381 kilotonnes N/year.

The biological nitrogen fixation (BNF) varies from 408 kilotonnes N/year in 1990 to 413 kilotonnes $\mathrm{N} /$ year in 2012. Error on these estimates was based on the ranges published in Smil (1999) and Cleveland et al. (1999) of $\pm 42 \%$. There is a significant $(p<0.05)$ linear decline in the BNF of -0.5 kilotonnes $N /$ year $^{2}\left(\mathrm{r}^{2}=0.47, \mathrm{n}=23\right)$. Assuming that this trend continues, the projected value by 2020 is 402 kilotonnes N/year.

The UK is a net importer of food and feed, and food imports have increased relative to exports since 1990 . In general, the UK is an importer of high-N, proteinrich foods (e.g. meat) and an exporter of grains. The net trans-boundary input of $\mathrm{N}$ in food and feed to the UK land area varied from 42 to 297 kilotonnes N/year between 1990 and 2012. There was a significant linear increase in the import of $\mathrm{N}$ in this form, the best-fit line giving an average annual increase of 11.2 kilotonnes N/year ${ }^{2}\left(r^{2}=0.82, n=23\right)$, predicting that by 2020 the food and feed input could be 428 kilotonnes N/year.

The input of synthetic inorganic fertilizer is by far the largest nitrogen input into the UK, varying between 1582 kilotonnes N/year in 1990 and 978 kilotonnes N/year in 2008. Inputs rose for the 3 years: 2010 to 2012 inclusive, but by 2014 the input was back down to 967 kilotonnes N/year. The input of synthetic inorganic fertilizer had a significant annual average decline since 1987 of 23 kilotonnes N/year ${ }^{2}$ (based upon best-fit line- $\mathrm{r}^{2}=0.88, \mathrm{n}=28$ ). Assuming that this trend continues, fertilizer inputs by 2020 would be 783 kilotonnes N/year. The decline in inorganic fertilizer inputs has been occurring since 1984, driven by rising cost, improvements in agronomic precision, and schemes to limit application rates, such as Nitrate Vulnerable Zones (NVZ) Worrall et al. (2009).

\section{$\mathrm{N}$ outputs}

Data for all output pathways are summarized in Table 1. The proportion of outputs represented by each pathway in 1990 compared to 2012 is shown in Fig. 3 with the breakdown of the budget being given in Table 1 for 1990, 2012 and projected to 2020 (all preferred values for $\mathrm{N}$ inputs are given in Table $\mathrm{S} 3$ ). 
Table 1 Summary of preferred values of N inputs and outputs for 1990 and 2012; and predicted fluxes and exports for 2020

\begin{tabular}{|c|c|c|c|c|c|c|c|}
\hline & $\begin{array}{l}\text { Flux in } 1990 \\
\text { (kilotonnes } \\
\text { N/year) }\end{array}$ & $\begin{array}{l}\text { Export in } \\
1990(\mathrm{~kg} \mathrm{~N} / \\
\text { ha/year })\end{array}$ & $\begin{array}{l}\text { Flux in } 2012 \\
\text { (kilotonnes } \\
\text { N/year) }\end{array}$ & $\begin{array}{l}\text { Export in } \\
2012(\mathrm{~kg} \mathrm{~N} / \\
\text { ha/year) }\end{array}$ & $\begin{array}{l}\text { Annual average } \\
\text { increase } \\
\text { (kilotonnes }^{2} \\
\text { N/year }{ }^{2} \text { ) }\end{array}$ & $\begin{array}{l}\text { Predicted flux } \\
\text { in } 2020 \\
\text { (ktonnes } \\
\text { N/year) }\end{array}$ & $\begin{array}{l}\text { Export in } \\
2020(\mathrm{~kg} \mathrm{~N} / \\
\text { ha/year) }\end{array}$ \\
\hline \multicolumn{8}{|l|}{ Input } \\
\hline $\begin{array}{c}\text { Atmospheric } \\
\text { deposition }\end{array}$ & 298 & 12.2 & 393 & 16.1 & 3.5 & 421 & 17.3 \\
\hline $\begin{array}{l}\text { Biological } \\
\text { nitrogen } \\
\text { fixation }\end{array}$ & 408 & 16.7 & 413 & 17.0 & -0.5 & 402 & 16.5 \\
\hline $\begin{array}{l}\text { Food \& feed } \\
\text { transfers }\end{array}$ & 42 & 1.7 & 297 & 12.2 & 11.2 & 428 & 17.5 \\
\hline $\begin{array}{l}\text { Inorganic } \\
\text { fertilizers }\end{array}$ & 1582 & 64.8 & 978 & 40.1 & -23 & 783 & 32.1 \\
\hline Sub-total & 2330 & 95.5 & 2081 & 89.4 & -8.1 & 2034 & 83.4 \\
\hline \multicolumn{8}{|l|}{ Output } \\
\hline $\begin{array}{l}\text { Atmospheric } \\
\text { emissions of } \\
\mathrm{N}_{2} \mathrm{O}, \mathrm{NH}_{3}\end{array}$ & 2115 & 86.7 & 872 & 35.7 & -54 & 659 & 27.0 \\
\hline $\begin{array}{l}\text { Atmospheric } \\
\text { emissions of } \mathrm{N}_{2}\end{array}$ & 231 & 09.5 & 294 & 12.0 & 10.6 & 348 & 14.3 \\
\hline $\begin{array}{l}\text { Terrestrial } \\
\text { denitrification } \\
\text { to } \mathrm{N}_{2}\end{array}$ & 203 & 09.3 & 209 & 8.6 & 0 & 205 & 8.4 \\
\hline $\begin{array}{l}\text { Fluvial losses at } \\
\text { source }\end{array}$ & 2332 & 95.6 & 2220 & 91.0 & -33 & 1709 & 70.0 \\
\hline Groundwater & 15 & 0.6 & 15 & 0.6 & -1.9 & 0 & 0.0 \\
\hline $\begin{array}{l}\text { Direct waste } \\
\text { losses }\end{array}$ & 135 & 5.5 & 49 & 02.0 & 3 & 55 & 2.3 \\
\hline Sub-total & 5031 & 202.9 & 3629 & 150.0 & -88.5 & 2976 & 122.0 \\
\hline Total $\mathrm{N}$ budget & 2690 & 110.2 & 1548 & 63.4 & -73.8 & 942 & 38.6 \\
\hline
\end{tabular}

Sub-totals and totals are given as the median based upon the stochastic combination of the input and output pathways. NB, The annual average increases for the total inputs, total outputs and total budget were calculated separately from their time series and so will not necessarily be the sum of the annual changes in each of their components

Fig. 2 Proportions of $\mathrm{N}$ inputs in 1990 and 2012
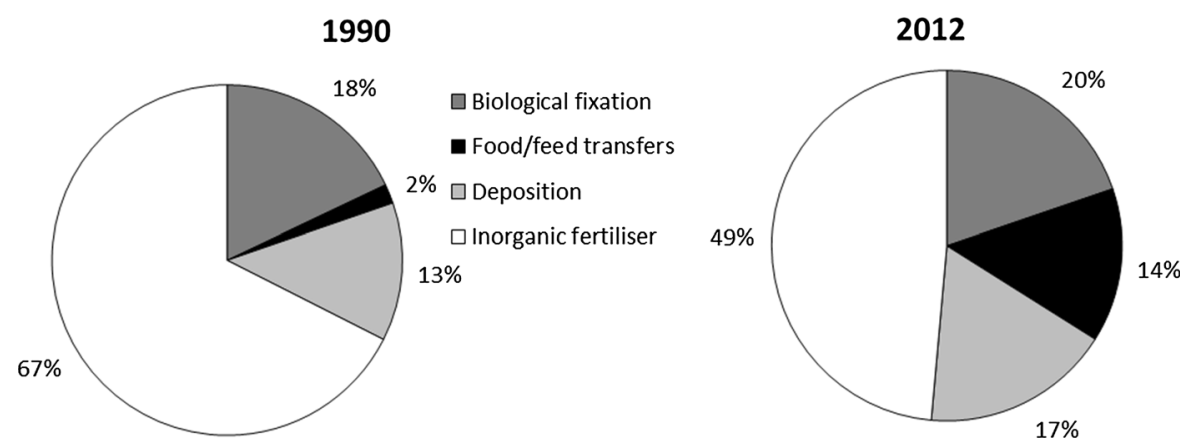

The total estimated emissions of $\mathrm{NOx}$ and $\mathrm{NH}_{3}$ to the atmosphere have declined from -2115 kilotonnes N/year in 1990 to -872 kilotonnes N/year in 2013.
Note that no uncertainty was given for these emissions and so the default uncertainty was used $\pm 80 \%$. This decline has been predominantly caused by a reduction 
1990

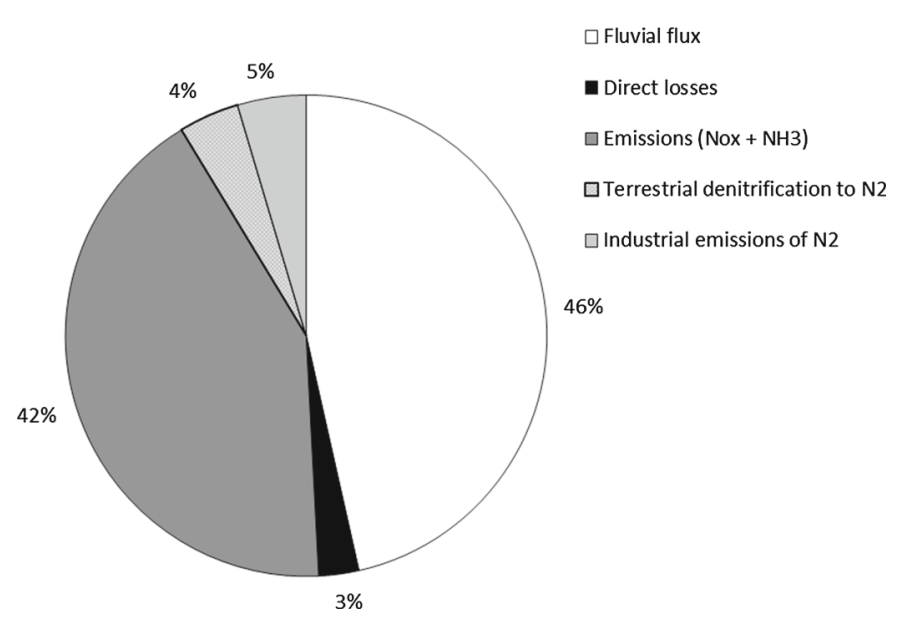

2012

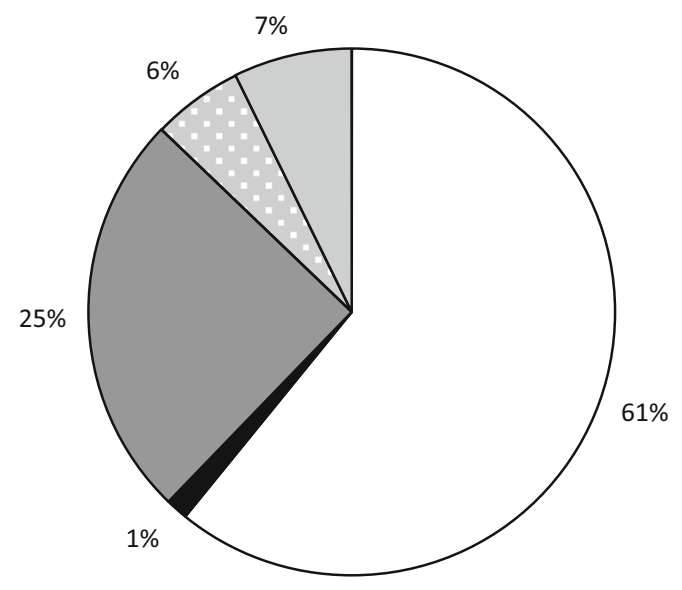

Fig. 3 Proportions of N outputs in 1990 and 2012

in $\mathrm{N}_{2} \mathrm{O}$ flux, which is estimated to have more than halved over the study period, largely a decline that we ascribed to UK government initiatives to meet its commitments under the Kyoto protocol. The total $\mathrm{NOx}$ and $\mathrm{NH}_{3}$ emissions peaked in 1989 and there has been a significant linear trend since then in the emission of $\mathrm{N}_{2} \mathrm{O}$ and $\mathrm{NH}_{3}$, with an estimated rate of decline of 54 kilotonnes N/year ${ }^{2}\left(r^{2}=0.98, n=25\right)$. However, the trend is marginally better described by quadratic curve $\left(\mathrm{r}^{2}=0.99, \mathrm{n}=25\right)$ with a decreasing gradient and using this approach the 2020 emission is predicted to be -659 kilotonnes N/year.

The estimated emissions of $\mathrm{N}_{2}$ from industrial sources, assessed using carbon emissions, have risen from -231 kilotonnes N/year in 1990 to -294 Kilotonnes N/year in 2013. There was a significant downward trend in industrial $\mathrm{N}_{2}$ emissions from 1974 to 2002 declining from -426 kilotonnes N/year in 1974 to -183 kilotonnes N/year in 2002. This decline was largely driven by reduction in the use of coal as an energy source. Since 2002 the increase has been driven by increased use of biomass as an energy source, biomass has a far larger $\mathrm{N}$ content than any of other energy source. Given the sharp change in the predicted $\mathrm{N}_{2}$ release in 2002, it is difficult to predict future emissions. There has been a significant increase in emissions since 2002 at a rate of 10.6 kilotonnes N/year ${ }^{2}\left(r^{2}=0.89, n=13\right)$-which would give a flux in 2020 of 348 kilotonnes/year. The approach outlined in the methodology means that the error on this pathway could be as much as $\pm 100 \%$.
Terrestrial denitrification to $\mathrm{N}_{2}$ has varied from -203 kilotonnes N/year in 1987 to -209 kilotonnes N/year in 1994, with no significant trend. The value in 2020 was, therefore, is taken from the range of these values, i.e. the median in 2020 would be estimated as 205 kilotonnes N/year. The error on this denitrification estimate, as set by the ranges reported by Barton et al. (1999) is $\pm 96 \%$.

The fluvial flux at the tidal limit has been extensively discussed by Worrall et al. (2009a) and is updated here. The total dissolved $\mathrm{N}_{\mathrm{r}}$ flux (nitrate, ammonium, and DON) increased from -574 kilotonnes N/year in 1990 to a maximum of -833 kilotonnes N/year in 2000. The estimate for 2012 was -591 kilotonnes N/year. The fluvial flux (dissolved and particulate) ranged from -632 kilotonnes N/year in 1990 to -682 kilotonnes N/year in 2012 having peaked in the year 2000. Comparing the years 1990 with the year 2012 for each component of the fluvial flux shows that, whilst fluxes of ammonia and nitrate have decreased, the fluxes of PON and DON have increased. The estimated error on the fluvial flux calculation is $\pm 15 \%$. There was a significant decrease in the total fluvial flux of -7 kilotonnes N/year ${ }^{2}\left(r^{2}=0.13\right.$, $\mathrm{n}=23$ ) and so by 2020 the flux is predicted to be -430 kilotonnes N/year.

The total flux of $\mathrm{N}$ from the terrestrial source to the fluvial network was -2332 kilotonnes N/year in 1990 and was estimated as -2220 kilotonnes N/year in 2012 but this is slightly misleading as there has been a significant decline in total $\mathrm{N}$ loss for the terrestrial 
source since 1990 at an average rate of -33 kilotonnes $\mathrm{N} /$ year $^{2}$. Total $\mathrm{N}$ loss for the terrestrial source peaked in the year 2000 at -3470 kilotonnes N/year. The significant trend predicts that by 2020 the total $\mathrm{N}$ flux from the terrestrial source to the fluvial network would be -1709 kilotonnes N/year. Therefore, the loss of $\mathrm{N}$ in transit through the fluvial network was -1700 kilotonnes N/year in 1990, peaked at -2485 kilotonnes N/year in the year 2000 and by 2012 the flux was -1539 kilotonnes N/year. The loss in transit declined significantly from 1990 to 2012 at rate of -25 kilotonnes/year ${ }^{2}\left(\mathrm{r}^{2}=0.21, \mathrm{n}=23\right)$ and thus by 2020 the loss would be -1191 kilotonnes N/year. Nitrate, DON and ammonia all declined over the study period whilst PON remained unchanged. It is possible there is no common cause behind these with some species being more related to agricultural practices and others due to urban changes.

Given the observations of Stuart et al. (2007) for UK groundwater then we have assumed that the sink to UK groundwater continues at a rate of -15 kilotonnes $\mathrm{N} /$ year. We would propose that given the relatively small size of this sink, the assumption that this sink would decrease to 0 by 2020 is reasonable. It should be noted that we have assumed that the denitrification of groundwater nitrate contributes nitrogen gases to the release from the terrestrial biosphere, but it may also exsolve from rivers as groundwater discharges to the surface and this would not appear in this study's estimate of the aquatic denitrification.

The total direct flux to the sea of $\mathrm{N}$ from sewage and industrial wastes has declined over the period of study from -135 kilotonnes N/year in 1990 to -49 kilotonnes N/year by 2012 with an average rate of decline of 3 kilotonnes N/year ${ }^{2} \quad\left(r^{2}=0.88, \quad n=23\right)$. Although there is a significant linear decline in direct fluxes, it is obvious from the plot of the time series that most of the decline in direct fluxes was achieved early in the 1990s. This sharp decline in direct waste emissions was due, in part, to actions taken to comply with the Urban Wastewater Treatment Directive (91/ 271/EEC: European Commission 1991). If a logarithmic response is fitted to the time series $\left(r^{2}=0.92\right.$, $\mathrm{n}=23$ ), then the flux by 2020 is predicted to be -55 kilotonnes N/year. As discussed above, no credible uncertainty assessment could be provided for this flux from the published source and so the default of uncertainty $( \pm 80 \%)$ was used.
Total $\mathrm{N}$ balance

The stochastic estimate of the budget suggests that total $\mathrm{N}$ was a net flux of $-1941 \pm 224$ kilotonnes $\mathrm{N} /$ year in 1990, where variation is quoted as the interquartile range, changing to a net flux of $-1446( \pm 195)$ kilotonnes N/year in 2012. This equates to an average export of -8.0 tonnes $/ \mathrm{km}^{2} /$ year in 1990 and -5.9 tonnes $\mathrm{N} / \mathrm{km}^{2} /$ year ( 80 to $59 \mathrm{~kg} \mathrm{~N} / \mathrm{ha} /$ year). Our analysis suggests that the source of total $\mathrm{N}$ from the UK is declining at a rate of about $22.4 \pm 1.9$ kilotonnes N/year ${ }^{2}$ (0.09 tonnes $/ \mathrm{km}^{2} /$ year or $0.9 \mathrm{~kg} \mathrm{~N} / \mathrm{ha} /$ year ${ }^{2}-r^{2}=0.55, n=23$-Fig. 4 ), but note that if the line is taken from the minimum in 1992 then the rate of source decline is at $73.8 \pm 6.2$ kilotonnes N/year ${ }^{2}$ (0.3 tonnes $/ \mathrm{km}^{2} /$ year or $3.0 \mathrm{~kg} \mathrm{~N} / \mathrm{ha} /$ year $\left.^{2}\right)$. Worrall et al. (2009a) estimated that the UK was a net sink for $\mathrm{N}_{\mathrm{r}}$ of between -17 and $-46 \mathrm{~kg} \mathrm{~N} / \mathrm{ha} / \mathrm{year}$, while de Vries et al. (2011) suggested that the $\mathrm{N}_{\mathrm{r}}$ budget was about $-3.2 \mathrm{~kg} \mathrm{~N} / \mathrm{ha} /$ year, based on an extrapolation of models across Europe. Projecting forward to 2020 yields a median predicted net flux would be a net flux of -1042 kilotonnes N/year (4.2 tonnes $\mathrm{N} / \mathrm{km}^{2} /$ year or $42 \mathrm{~kg} \mathrm{~N} / \mathrm{ha} /$ year) with an interquartile range of -909 to -1288 kilotonnes N/year-Fig. 4. During the study period, the total $\mathrm{N}$ inputs decreased at an average rate of 8.1 kilotonnes N/year ${ }^{2}\left(r^{2}=0.39, n=23\right)$ declining from 2330 $( \pm 70)$ kilotonnes N/year in 1990 to $2081( \pm 142)$ kilotonnes N/year (Fig. 5) while the outputs declined from -5031 $( \pm 193)$ kilotonnes N/year in 1990 to -3629 ( \pm 249$)$ kilotonnes N/year in 2012 and declining at an average rate of 88.5 kilotonnes $\mathrm{N} / \mathrm{year}^{2}$ $\left(r^{2}=0.67, n=23\right)$, i.e. both the inputs and outputs have declined but the outputs are declining far faster.

\section{Discussion}

Has this study provided an adequate account of the total $\mathrm{N}$ budget of the UK? It is difficult, if not impossible, to estimate a complete $\mathrm{N}$ budget at national or wider scales. However, reversal of the predicted trend would require an increase in source strength at a rate greater than 85 kilotonnes N/year ${ }^{2}$ which is an unrealistic proposition.

The results presented here suggest that the UK is currently a net exporter of nitrogen to its surrounding atmospheric and marine environments. Net losses of 


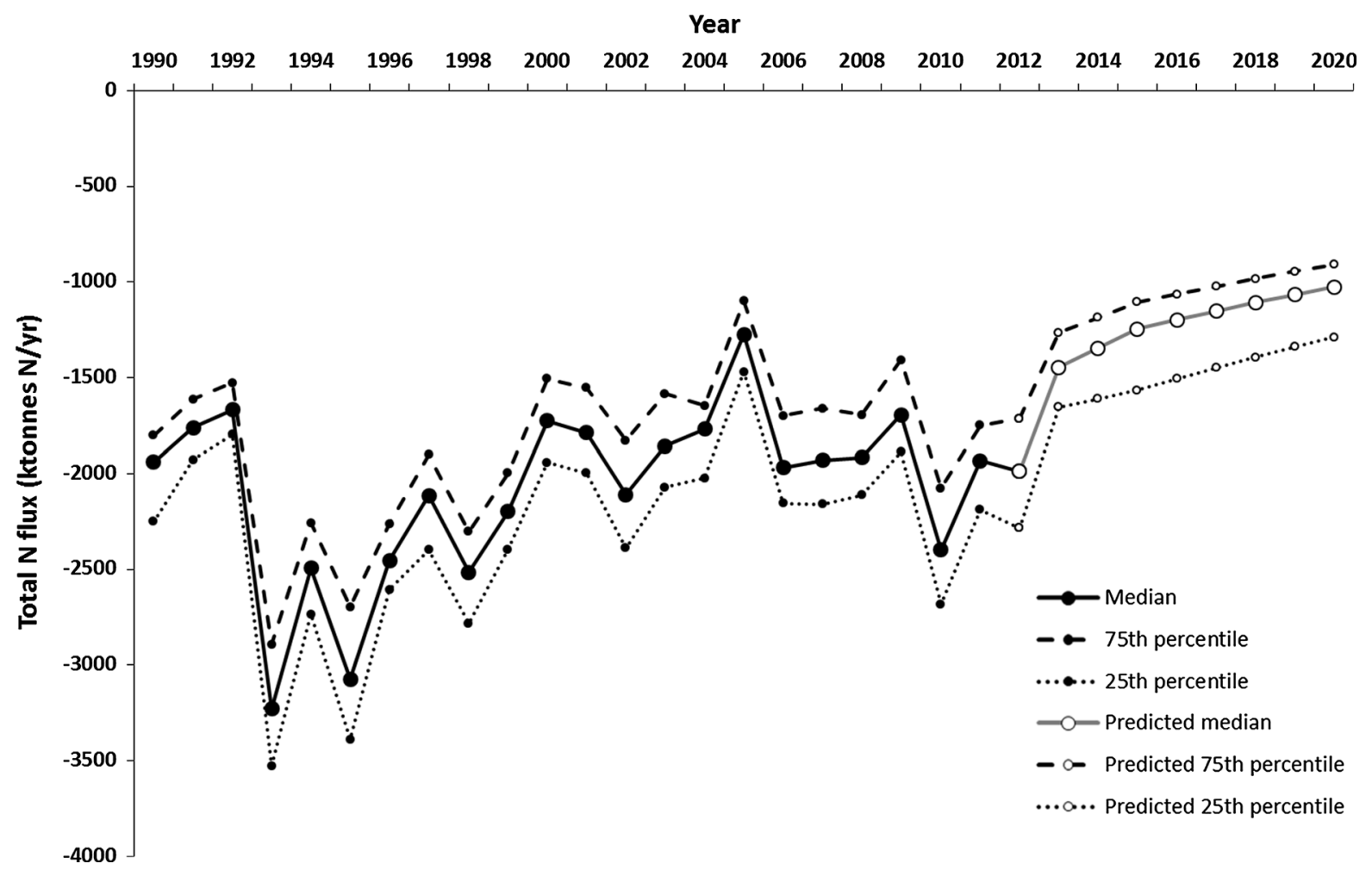

Fig. 4 The time series of the stochastic total N budget between 1990 and 2012 with the projection to 2020 . NB by the convention of the study a negative flux is a source from the UK

Inputs

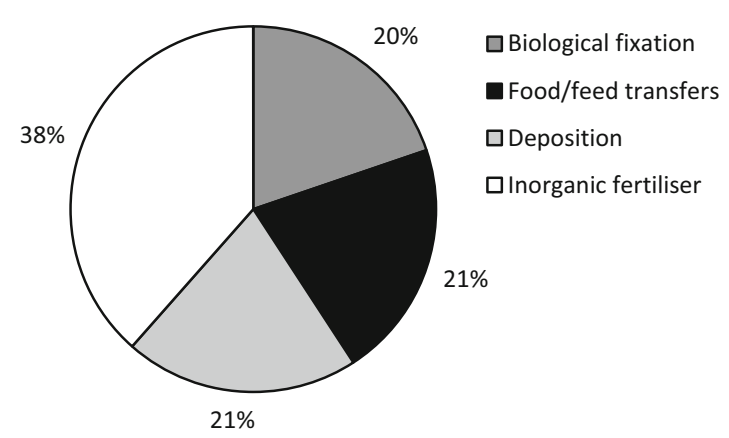

Fig. 5 Proportions of $\mathrm{N}$ inputs and outputs projected for 2020

nitrogen are decreasing, but the UK is unlikely to become a net sink for $\mathrm{N}$ before 2020 but at current trends the UK would become a net sink of total $\mathrm{N}$ in 2031. The net sink status may come about for a number of reasons. The UK is a heavily industrialized group of islands with a high population density and widespread intensive agriculture: all this leads to high atmospheric and fluvial emissions. What perhaps is
Outputs

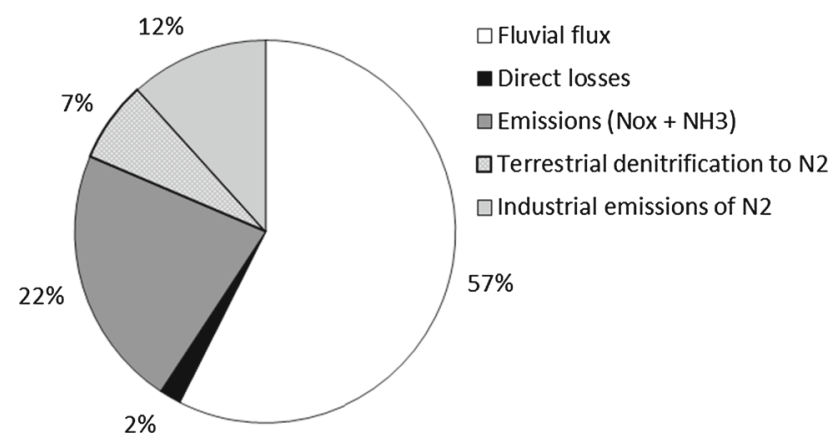

more remarkable is not that the UK is a net source of total $\mathrm{N}$ but that the size of the total flux is decreasing and the country may become a net sink in the near future. Note that the UK is predicted to be a net sink of $\mathrm{N}_{\mathrm{r}}$ (Worrall et al. 2009). The study has shown that the largest export is via the fluvial system closely followed by atmospheric emissions-fluvial flux at source was $61 \%$ of outputs in 2012 . Over the course of the study 
period, the atmospheric emissions and the fluvial flux at the terrestrial source have declined. At the same time, only the input of inorganic fertilizer has decreased appreciably. Therefore, the total net $\mathrm{N}$ source has decreased because emissions have declined rather than inputs have increased. The reduction in land to air NOx transfer is being driven by legislation to reduce greenhouse gas emissions and could decline further as a result of future climate change treaties. It should also be noted that reduced NOx emissions implies a reduction in the industrial source of $\mathrm{N}_{2}$ as well, although this is not directly legislated for and the increase in the use of biomass for energy may thwart this.

It is difficult to predict whether input and output pathways, other than atmospheric emissions, will follow the trend predicted here. Direct losses to the sea of $\mathrm{N}$ in waste are unlikely to follow a linear trend as the largest decreases have already been achieved. Terrestrial denitrification is related to land use and inputs. The predictions presented here are based on limited information which distinguishes between fertilised and unfertilised land but does not account for the relationship between denitrification and fertilizer input. Given the documented decline in inorganic fertilizer applications, a reduction in terrestrial denitrification might, therefore, also have occurred over the study period and may continue to decline if inorganic fertilizer usage also declines. van Breeman et al. (2002) have suggested that terrestrial denitrification can typically represent $35 \%$ of $\mathrm{N}$ inputs. At a fixed rate of $35 \%$ of input, the terrestrial denitrification would be -724 kilotonnes N/year in 1990 declining by 8 kilotonnes $N / y_{e a r}{ }^{2}$ : this is higher than the estimate of terrestrial denitrification predicted here. Either way, the trend captured in this study (i.e. diminishing source becoming a sink) is supported.

The trend in food and feed transfers is heavily dependent upon shifts in global markets. Even if climate change should improve conditions for agriculture in the UK (e.g. drier summers lead to greater production of the valuable export product, such as bread wheat, as opposed to the less valuable feed wheat in northern England) and the UK becomes a net exporter of food, it might still be a net importer of $\mathrm{N}$ in food and feed. The balance of food/feed transfers does have an important implication for use of inorganic fertilizers. It could be that, as the UK becomes a net exporter of $\mathrm{N}$ in food, it does so at the expense of increased inorganic fertilizer use or at least at a levelling off in the current decline in fertilizer use.

The fluvial flux has a more predictable behaviour: the total fluvial $\mathrm{N}$ flux at source appears to be in moderate decline for the next decade. In fact, losses at the terrestrial source appears to be declining faster than the flux at the tidal limit, but this may be due to the nature of the different methods used to measure each rather than any implication about changing nature of in-stream processing. There have been no large and widespread land use changes in the last decade which might drive losses via, for example, enhanced net mineralisation of soil organic matter (Whitmore et al. 1992). This is supported by water quality time series data from a number of catchments which show that nitrate concentrations have remained constant or in slight decline for the last decade or so (e.g. Burt et al. 2008) except where there is a significant contribution of groundwater with a long residence time (Howden et al. 2010, 2011). Worrall et al. (2012) have suggested that, in some catchments, the fluvial flux of nitrate at the tidal limit may eventually be larger than the nitrogen losses from soil as "old", long residence time, high nitrate concentration groundwater starts to appear in surface waters.

The outcome presented could be sensitive to the uncertain results of one particular pathway. Between 1990 and 2012 the input pathway with the single largest magnitude is the input of inorganic fertilizer. However, the input of fertilizer is well known with very low comparative uncertainty, and therefore, $10 \%$ additional effort in the collection of fertilizer information may not have the greatest impact on the uncertainty in the total $\mathrm{N}$ budget. Alternatively, if we express the uncertainty in each pathway as a percentage of the total budget in 2012 then we find that the total $\mathrm{N}$ budget estimation is most sensitive to the uncertainty in the estimation of the emission of NOx and $\mathrm{NH}_{3}$ - (uncertainty being $45 \%$ of total $\mathrm{N}$ budget estimate) but this is closely followed by the fluvial flux at the terrestrial source where the uncertainty represents $44 \%$ if the total $\mathrm{N}$ budget in that year, i.e. the uncertainty in two pathways alone are almost the entire magnitude of the estimated total $\mathrm{N}$ budget. Therefore, we would propose that the greatest effort be placed into understanding these terms rather than any other.

No account has been taken here of the potential effects of climate change on the nitrogen fluxes 
considered. However, it is feasible that changes in temperature, rainfall patterns and atmospheric $\mathrm{CO}_{2}$ concentration (including the projected increased frequency in extreme events: c.f. Burt and Ferranti 2010) may influence the nitrogen balance at the national scale. For example, increases in temperature have been linked to increased losses of soil organic carbon (Smith et al. 2007) which may be associated with a loss of soil organic nitrogen-most probably as fluvial nitrate. The loss of DON should continue to increase in response to recovery from acidification (Monteith et al. 2007) and this may be exacerbated by higher temperatures (Worrall and Burt 2007).

It should be emphasized that the $\mathrm{N}$ budget calculated in this study is for the whole of the UK and not for the terrestrial biosphere within the UK. It is possible that, while the UK as a unit represents a net sink or source, the sign of the net flux from the terrestrial biosphere might be different. The main reason that this study has predicted a transition for the UK acting as a net source towards acting as a net sink is due to declines in $\mathrm{N}$ emissions to the atmosphere and in fertilizer applications. To estimate the net $\mathrm{N}$ budget of the UK terrestrial biosphere, the budget presented here needs to be recalculated without the industrial emissions of $\mathrm{NOx}, \mathrm{NH}_{4}$ and $\mathrm{N}_{2}$. If this was done, then the terrestrial biosphere would represents a $\mathrm{N}$ budget with a magnitude of between -528 and 1573 kilotonnes N/year ( -22 and $65 \mathrm{~kg} \mathrm{~N} / \mathrm{ha} /$ year), i.e. the terrestrial biosphere could be a sink or source but the median value was 372 kilotonnes N/year. This implies that the overall budget of the terrestrial biosphere is highly sensitive to changes in some inputs, however, there is some accumulation of $\mathrm{N}$ in the terrestrial system. Indeed, Worrall et al. (2015) have shown total $\mathrm{N}$ accumulation for the Thames catchment but in what form and where the accumulation is occurring remains unclear. The other source terms in this total $\mathrm{N}$ budget are being driven by unlocking of fossil fuels reserves of $\mathrm{N}$ but it should also be remembered that most inorganic fertilizer $\mathrm{N}$ is coming from $\mathrm{N}$ either extracted from the atmosphere or from natural gas fields.

\section{Conclusions}

This study has estimated that the UK was a source of total $\mathrm{N}$ to its surrounding environment of between
-1941 and -1446 kilotonnes N/year between 1990 and 2012 with a significant annual average decline of 22.4 kilotonnes N/year ${ }^{2}$. Extrapolation of current trends to 2020 suggests that the total $\mathrm{N}$ budget of the UK will be -1042 (interquartile range -909 to -1288 ) kilotonnes N/year. The size of the future total $\mathrm{N}$ budget and the magnitude of the trend are critically dependent upon future changes in atmospheric emissions and fertilizer inputs, current trends suggest the UK will become a net sink of total $\mathrm{N}$ by 2031 .

Open Access This article is distributed under the terms of the Creative Commons Attribution 4.0 International License (http:// creativecommons.org/licenses/by/4.0/), which permits unrestricted use, distribution, and reproduction in any medium, provided you give appropriate credit to the original author(s) and the source, provide a link to the Creative Commons license, and indicate if changes were made.

\section{References}

Addiscott TM (1998) Long-term leakage of nitrate from bare unmanured soil. Soil use manage 4:91-95

Ayres RU, Schlesinger WH, Socolow RH (1994) Human impacts on the carbon and nitrogen cycles. In: Socolow RH, Andrews C, Berkhout R, Thomas V (eds) Industrial ecology and global change. Cambridge University Press, New York, pp 121-155

Barton L, McClay CDL, Schipper LA, Smith CT (1999) Annual denitrification rates in agricultural and forest soils. Aust $\mathbf{J}$ Soil Res 37:1073-1093

Bellamy D, Wilkinson P (2001) Ospar 98/3: an environmental turning point or a flawed decision? Mar Pollut Bull 49:87-90

Benitez JMG, Cape JN, Heal MR, van Dijk N, Diez AV (2012) Atmospheric nitrogen deposition in south-east Scotland: quantification of the organic nitrogen fraction in wet, dry and bulk deposition. Atmos Environ 43(26):4087-4094

Billen G, Garnier J, Thien V, Silvestre M, Barles S, Chatzimpiros $P$ (2012) Localising the nitrogen imprint of the Paris food supply: the potential of organic farming and changes in human diet. Biogeosciences 9:607-616

Boyer EW, Goodale CJ, Jaworski NA, Howarth RW (2002) Anthropogenic nitrogen sources and relationships to riverine nitrogen export in the northeastern USA. Biogeochemistry 57(58):137-169

Boyer EW, Howarth RW, Galloway JN, Dentener FJ, Green PA, Vorosmarty CJ (2005) Riverine nitrogen export from the continents to the coasts. Global Biogeochem Cycles 26:191

Brimblecombe P (1996) Air composition and Chemistry, 2nd edn. Cambridge University Press, Cambridge

British Survey of Fertiliser Practice (2013) Fertiliser use on farm crops for crop year 2013. HMSO, London

Burchill P, Welch LS (1989) Variation of nitrogen content and functionality with rank for some UK bituminous coals. Fuel 68(1):100-104

Burt TP, Ferranti EJS (2010) Changing patterns of heavy rainfall in upland areas: a case study from northern England. Int $\mathbf{J}$ Climatol. doi:10.1002/joc.2287 
Burt TP, Howden NJK, Worrall F, Whelan MJ (2008) Importance of long-term monitoring for detecting environmental change: lessons from a lowland river in south east England. Biogeosciences 5:1529-1535

Cape JN, Tang YS, Gonzalez-Benitez JM, Mitosinkova M, Makkonen U, Jocher M, Stolk A (2012) Organic nitrogen in precipitation across Europe. Biogeosciences 9(11):4401-4409

Cleveland CC, Townsend AR, Schimel DS, Fisher H, Howarth RW, Hedin LO, Perakis SS, Latty EF, Von Fischer JC, Elseroad A, Wasson MF (1999) Global patterns of terrestrial biological nitrogen fixation in natural systems. Global Biogeochem Cycles 13:623-645

Commission OSPAR (2010) Data report on the comprehensive study of riverine inputs and direct discharges (RID) in 2007. OSPAR Commission, Paris

Commission Forestry (2011) Forestry facts and figures. The Forestry Commission, Edinburgh

Dalgaard T, Hutchings N, Dragosits U, Oleson JE, Kjeldsen C, Drouet JL, Cellier P (2011) Effects of farm heterogeneity and methods for upscaling on modelled nitrogen losses in agricultural landscapes. Environ Pollut 159(11):3183-3192

de Vries W, Leip A, Reinds GJ, Kros J, Lesschen JP, Bouwman AF (2011a) Comparison of land nitrogen budgets for European agriculture by various modeling approaches. Environ Pollut 159:3253-3267

de Vries W, Leip A, Reinds G-J, Kros J, Lesschen JP, Bouwman AF, Grizzetti B, Bouraoui F, Butterbach-Bahl K, Bergamaschi P, Winiwarter W (2011b) Geographical variation in terrestrial nitrogen budgets across Europe. In: Sutton MA, Howard CM, Willem-Erisman I, Billen G, Blecker A, Grennfelt P, van Grimsven H, Grizzetti B (eds) European Nitrogen Assessment. Cambridge University Press, Cambridge

DECC (2012) through 2015) UK energy in brief. Department of Energy and Climate Change, HMSO

DEFRA (2001) through 2010) Agriculture in the United Kingdom. Department of Environment, Food and Rural Affairs, HMSO, London

Dore C, Watterson J, Murrells T, Passant N, Hobson M, Choudrie SL, Thistlethwaite G, Wagner A, Jackson J, Li Y, Bush T, King KR, Norris J, Coleman PJ, Walker C, Stewart RA, Goodwin JWL, Tsagatakis L, Connolly C, Downes MK, Brophy N, Hann MR (2007) UK emissions of air pollutants 1970 to 2005. AEA Technology, Harwell

Etheridge DM, Steele LP, Francey RJ, Langenfelds RL (1998) Atmospheric methane between $1000 \mathrm{AD}$ and present: evidence of anthropogenic emissions and climatic variability. J Geophys Res 103:15979-15993

Fowler D, Smith RL, Muller JBA, Hayman G, Vincent KJ (2005) Changes in the atmospheric deposition of acidifying compounds in the UK between 1986 and 2001. Environ Pollut 137:15-25

Galloway JN, Dentener FJ, Capone DG, Boyer EW, Howarth RW, Seitzinger SP, Asner GP, Cleveland CC, Green PA, Holland EA, Karl DM, Michaels AE, Porter JH, Townsend AE, Vorosmarty CJ (2004) Nitrogen cycles: past, present and future. Biogeochemistry 70:153-226

Hemond HF (1983) The nitrogen budget of Thoreau's bog. Ecology 64(1):99-109

Herridge DF, Peoples MH, Boddy RM (2008) Global inputs of biological nitrogen fixation in agricultural systems. Plant Soil 311:1-18
Howarth RW, Swaney DP, Boyer EW, Marino RM, Jaworski N, Goodale CJ (2006) The influence of climate on average nitrogen export from large watersheds in the Northeastern United States. Biogeochemistry 79:163-186

Howden NJK, Burt TP, Worrall F, Whelan MJ, Bieroza M (2010) Nitrate concentrations and fluxes in the River Thames over 140 years (1868 to 2008): are increases irreversible? Hydrol Process 24:2657-2662

Howden NJK, Burt TP, Mathias SA, Worrall F, Whelan MJ, Bieroza MZ (2011) Modelling long-term diffuse nitrate pollution at the catchment-scale: data, parameter and epistemic uncertainty. J Hydrol 403:337-351

Janzen HH, Beauchemin KA, Bruinsma Y, Campbell CA, Desjardine RL, Ellert BH, Smith EG (2003) The fate of nitrogen in agroecosystems: an illustration using Canadian estimates. Nutr Cycl Agroecosyst 67:85-102

Kroeze C, Aerts R, van Breemen N, van Dam D, van der Hoek K, Hofschreuder P, Hoosbeek M, de Klein J, Kros H, van Oene H, Oenema O, Tietema A, van der Veeren R, de Vries W (2003) Uncertainities in the fate of nitrogen I: an overview of sources of uncertainty illustrated with a Dutch case study. Nutr Cycl Agroecosyst 66:43-69

Krooss BM, Littke R, Müller B, Frielingsdorf J, Schwochau K, Idiz EF (1995) Generation of nitrogen and methane from sedimentary organic matter: implications on the dynamics of natural gas accumulations. Chem Geol 126:291-318

Leip A, Achermann B, Billen G, Bleeker A, Bouwman AF, Vries W, Dragosits U, Döring U, Fernall D, Geupel M, Johnes P, Le Gall AC, Monni S, Neveceral R, Orlandini L, Prud'homme M, Reuter HI, Simpson D, Seufert G, Spranger T, Sutton MA, van Aardenne J, Voß M, Winiwarter W (2011) Integrating nitrogen fluxes at the European scale. In: Sutton MA, Howard C, Erisman JW, Billen G, Bleeker A, Grennfelt P, van Grinsven H, Grizzetti B (eds) The European nitrogen assessment. University Press, Cambridge, pp 345-376

Lord EI, Anthony SG, Gondlass G (2002) Agricultural nitrogen balance and water quality in the UK. Soil Use Manage 18:363-369

MAFF (1975/2000) Agriculture in United Kingdom. Ministry of Agriculture Fisheries and Food HMSO, London

Mariotti A (1986) Denitrification in groundwaters, principles and methods for its identification: a review. J Hydrol 88:1-23

Marsh TJ (1980) Towards a nitrate balance for England and Wales. Water Services 84:1016

McCance RA, Widdowson EM (2002) The composition of foods, 5th edn. HMSO, London

Monteith DT, Stoddard JL, Evans CD, de Wit HA, Forsius M, Hogesan T, Wilander A, Skjelkvale BL, Jefferies DS, Vuorenmaa J, Keller B, Kopacek J, Vesely J (2007) Dissolved organic carbon trends resulting from changes in atmospheric deposition chemistry. Nature 450(7169):537-541

Neal C (2003) Dissolved and acid available particulate beryllium in eastern UK surface waters. Sci Total Environ 314:185-208

Neuwirth R (2008) Natural gas processing-nitrogen removal from natural gas: technical and economical evaluation of processes for nitrogen removal. Verlag, Berlin, p 132

OECD (2003) Gross nitrogen balances handbook. OECD, Paris

Oláh J, Oláh M (1996) Improving landscape nitrogen metabolism in the hungarian lowlands. Ambio 25(5):331-335 
Parfitt RL, Baisden WT, Schipper LA, Mackay AD (2008) Nitrogen inputs and outputs for New Zealand at national and regional scales: past, present and future scenarios. J R Soc NZ 38:71-81

Parris K (1998) Agricultural nutrient balance as agri-environmental indicators: an OECD perspective. Environ Pollut 102:219-225

Rickard GK, Fulker R (1997) The quality of aviation fuel available in the United Kingdom, Annual Survey-Technical Report DERA/SMC/SM1/TR970039. Defence Evaluation and Research Agency, Farnborough, p 35

Robson AJ, Neal C (1997). A summary of regional water quality for Eastern UK rivers. Sci Total Environ 194-195:15-37

Rossi AM, Villarreal M, Juarez MD, Samman NC (2004) Nitrogen contents in food: a comparison between the Kjeldahl and Hach methods. J Argent Chem Soc 92:99-108

Salo T, Lemola R, Esala M (2007) National and regional net nitrogen balances in Finland in 1990-2005. Agricult Food Sci 16:366-375

Schlesinger WH, Bernhardt ES (2013) Biogeochemistry: an analysis of global change, 3rd edn. Academic Press, Waltham

Simpson EA (1980) The harmonization of the monitoring of the quality of rivers in the United Kingdom. Hydrol Sci Bull 25:13-23

Simpson D, Aas W, Bartnicki J, Berge H, Blecker A, Cuvelier K, Dentener F, Dore A, Willem-Erisman J, Fagerli H, Flechard C, Hertel O, van Jaarsveld H, Jenkin M, Schaap M, Shamsudheen-Semeena V, Thunis P, Vautard R, Vieno M (2011) Atmospheric transport and deposition of reactive nitrogen in Europe. In: Sutton MA, Howard CM, WillemErisman I, Billen G, Blecker A, Grennfelt P, van Grimsven H, Grizzetti B (eds) European Nitrogen Assessment. Cambridge University Press, Cambridge

Smil V (1999) Nitrogen in crop production: an account of global flows. Global Biogeochem Cycles 13(2):647-662

Smith P, Chapman SJ, Scott WA, Black HIJ, Wattenbach M, Milne R, Campbell CD, Lilly A, Ostle N, Levy PF, Lumsdon DG, Millard P, Towers W, Zaehle S, Smith JU (2007) Climate change cannot be entirely responsible for soil carbon loss observed in England and Wales, 1978-2003. Glob Change Biol 13:2605-2609

Sowers T, Rodebaugh A, Yoshida N, Toyoda S (2002) Extending records of the isotopic composition of atmospheric $\mathrm{N}_{2} \mathrm{O}$ back to $1800 \mathrm{AD}$ from air trapped in snow at the South Pole and the Greenland Ice Sheet Project II ice core. Global Biogeochem Cycles 18:1129

Spahni R, Chapelle J, Stocker TF, Loulergue L, Hausamann G, Kawamura K, Fluckiger J, Schwander J, Raynaud D, Masson-Delmonte V, Jouzel J (2005) Atmospheric methane and nitrous oxide of the late Pleistocene from Antarctic ice cores. Science 310:1317-1321

Stuart ME, Chilton PJ, Kinniburgh DG, Cooper DM (2007) Screening for long-term trends in groundwater nitrate monitoring data. Q J Eng Geol Hydrogeol 40:361-376

Sutton MA, Howard CM, Willem-Erisman I, Billen G, Blecker A, Grennfelt P, van Grimsven H, Grizzetti B (2011a) European nitrogen assessment. University Press, Cambridge

Sutton MA, Howard CM, Willem-Erisman I, Bealey WJ, Billen G, Blecker A, Bouwman AF, Grennfelt P, van Grinsven H,
Grizetti B (2011b) The challenge to integrate nitrogen science and policies: the European nitrogen assessment approach. In: Sutton MA, Howard CM, Willem-Erisman I, Billen G, Blecker A, Grennfelt P, van Grimsven H, Grizzetti B (eds) European Nitrogen Assessment. Cambridge University Press, Cambridge

Thomas J, Thistlethwaite G, MacCarthy J, Pearson B, Murrells T, Pang Y, Passant N, Webb N, Conolly C, Cardenas L, Malcolm H, Thomson A (2011) Greenhouse gas inventories for England, Scotland, Wales and Northern Ireland: 1990-2009 AEA Technology. Harwell, UK

Ti C, Pan J, Xia Y, Yan X (2011) A nitrogen budget of mainland China with spatial and temporal variation. Biogeochemistry. doi:10.1007/s10533-011-9606-y

van Breemen N, Boyer EW, Goodale CL, Jaworski NA, Paustian K, Seitzinger SP, Lajtha K, Mayer B, van Dam D, Howarth RW, Nadelhoffer KJ, Eve M, Billen G (2002) Where did all the nitrogen go? Fate of nitrogen inputs to large watersheds in the northeastern USA. Biogeochemistry 57(58):267-293

Whitmore AP, Bradbury NJ, Johnson PA (1992) Potential contribution of ploughed grassland to nitrate leaching. Agric Ecosyst Environ 39:221-233

Wolff E, Spahni R (2007) Methane and nitrous oxide in ice core record. Phil Trans Roy Soc A 365:1775-1792

European Commission (1991) Directive concerning urban wastewater treatment council directive 97/271. J Eur Union 375(31): 12

Worrall F, Burt TP (2007) Trends in DOC concentration in Great Britain. J Hydrol 346(3-4):81-92

Worrall F, Burt TP, Adamson JK (2006) Do nitrate inputs stimulate DOC production in upland peat bogs? Global Biogeochem Cycles 20(3):3013

Worrall F, Guillbert T, Besien T (2007) The Flux of Carbon from rivers: the case for flux from England and Wales. Biogeochemistry 86:63-75

Worrall F, Burt TP, Howden NJK, Whelan MJ (2009a) The fluvial flux of nitrogen from great britain 1974-2005 in the context of the terrestrial nitrogen budget of Great Britain. Global Biogeochem Cycles 23:3017

Worrall F, Spencer E, Burt TP (2009b) The effectiveness of nitrate vulnerable zones for limiting surface water nitrate concentrations. J Hydrol 370(1-4):21-28

Worrall F, Davies H, Burt TP, Howden NJK, Whelan MJ, Bhogal A, Lilly A (2012a) The flux of dissolved nitrogen from the UK-predicting the role of soils and land use. Sci Total Environ 434:90-100

Worrall F, Burt TP, Howden NJK, Whelan MJ (2012b) Understanding the fluvial flux of nitrates from the terrestrial biosphere-the use of a national-scale export model. J Hydrol 414:31-39

Worrall F, Burt TP, Howden NJK (2014) The fluvial flux of particulate organic matter from the UK: quantifying in stream losses and carbon sinks. J Hydrol 519:611-625

Worrall F, Howden NJK, Burt TP (2015) Evidence for nitrogen accumulation: the total nitrogen budget Thames budget. Biogeochemistry 123:411-428

Worrall F, Burt TP, Howden NJK (2016) The fluvial flux of particulate organic matter from the UK: the emission factor of soil erosion. Earth Surf Proc Land 41(1):61-71 